\title{
Stem Bark Extract Bioactivity of Odorata Lour Aglaia (Meliaceae) Plant on the Deterrent to Oviposition Activities of crocidolomia pavonana fab
}

\author{
Rusli Sigar, S.J. Rondonuwu, J. Posangi and O.R. Pinontoan \\ Faculty of Agriculture, University of Sam Ratulangi, Indonesia
}

\begin{abstract}
One of the family members of Meliaceae that now widely studied in its insecticidal activity is Aglaia genus. Some research results showed that the extracts of the plants A. argantea, A. odorata, A. elliptica, and A. odorattisima can deter the development and growth of insect. Crocidolomia pavonana is major pest of cabbage and inflict severe damage on cabbage plants. Instar 3 larval stage is the active stage of the meal. The part of cabbage that was destroyed is the growing point, so that the formation of the cabbage crop does not happen. The purpose of this research was to test the bioactivity of the stem bark extract of A. odorata against the deterrent activity of $C$. pavonana. Plant extracts were obtained by maseration method using methanol. The tested insects were male and adult female C. pavonana. Oviposition Deterrent Index of (IPO) at concentration of extract $0,25 \%$ was 0.12 , on concentration $0.50 \%$ was 0.35 , on concentration $0.75 \%$ was 0.66 and on concentration $1 \%$ was 0.95 . This means that in every treatment there is a different number of eggs laid. The highest Oviposition Deterrent Index is at a concentration of $1 \%$ which is 0.95 .
\end{abstract}

Keywords : Aglaia Genus, Crocidolomia Pavonana, Stem Bark Extract

\section{Introduction}

Crocidolomia pavonana $(\mathrm{F})$ insect pest is a major pest insect (key pest) on cabbage plants (The family of Brassicaceae). The life cycle of this insect is the perfect metamorphosis that starts from the eggs, larvae, pupae stage and the imago stage. Young larvae eats the bottom surface of the leaves and tend to avoid sunlight. His favorite part of the plant is from young leave to the growing point, so it is often called crop worm or growing point caterpillar (Sastrosiswojo and Setiawati, 1993).

C. pavonanam larvae causes damage by eating the leaves from the bottom surface and the upper layers of the epidermis leaving symptoms of a dreamy window on the leaves. Damage inflicted on cabbage plants can reach 100\%, especially in the dry season (Sastrosiswojo and Setiawati, 1996).

This is a major insect pests on cabbage plants that can result in yield losses up to 65.8\% (Uhan, 1993). This pest is very troubling because its ability to choose the host as a source of life can come to the level of cultivars. Pelealu (2004) stated that C. pavonana pest can choose host to the level of cultivars, as well as on the preference oviposition on cultivars correlated with stimulation intensity of ecological factor of. Early instar larvae feed on the leaves and leave the epidermal layer which is then perforated after the epidermal layer dry. Upon reaching the third instar larvae disperse and attack the deeper then broaching into the crop and destroy the growing point.

Application of Integrated Pest Management (IPM) in the Brassicaceae plant has been carried out since 20 years ago. Control tactics were applied to address the problem of pests C. pavonana including the use of parasitoids, the use of selective insecticides and technical culture control (Setiawati \& Sastrosiswojo, 1996). One group of selective insecticides that can be used to support the implementation of Integrated Pest Management (IPM) on cabbage plants, including pest control C. pavonana namely the use of botanical insecticides. This group is environmentally friendly insecticides because generally not toxic to natural enemies of pests and easily decompose in nature. In addition, the use of botanical insecticide containing a mixture of the active compound can suppress the emergence of pest resistance (Prijono, 1999).

More than 2400 plant species included in 235 families are reported to contain pesticide ingredient (Grainge \& Ahmed, 1988). Some genus of plants that have good prospects as a source of botanical insecticides include Azadirachta, Aglaia, and Dysoxylum (Meliaceae) (Satasook et al., 1994, Schmutterer, 1995; Prijono et 
al., 2004). To be able to control C. pavonana pest appropriately and integrated, required a thorough understanding of the biology of the pest include morphological characteristics, the potential for growth and development and owned behavior, among which oviposi behavior. In lepidoptera order insect, the selection of host stages in the process of egg laying (oviposition) is very important because the selected host can affect the survival of larval offspring (Renwick \& Chew, 1994).

One of Meliaceae family species as a potential source of botanical insecticide is Aglaia. Acetone extract of Aglaia harmsiana seed can deter the eating activity and the development pre-mature C. pavonana (Prijono, 1998) as well as suppress the reproductive ability and laying eggs imago C. pavonana (Wiyantono et al., 2001). Prijono et al. 2001 reported that one of the active fraction of the bark of D. acutangulum was a strong insecticidal activity against the larvae of C. pavonana with $6,6 \% \mathrm{LC}_{50}$. The poisoning symptoms due to treatment with the D. acutangulum extract and its active fraction are the failure of molting, and the larvae usually die before or during the molt (Prijono et al., 2004). The research on the activity of active fraction insecticide of stem bark of A. odorata on the oviposition deterrent to C. pavonana has not been reported yet.

\section{Materials and Methods}

The experiment was conducted in Biology laboratory of Faculty of Science University of Sam Ratulangi, in field trials of Sam Ratulangi University in Campus, and Wailan Village Kakaskasen District in Tomohon City, North Sulawesi.

\section{Source Extract}

Plant material used as the source of the extract in the implementation of this study was the stem bark of A. odorata plant taken from the area around Kotamobagu smallholders.

\section{Insects Propagation Test}

Imago Crocidolomia pavonana taken from Unsrat's plantation area, Wailan village in Tomohon, then propagated and maintained following the method described by Pelealu (2004). Imago insects reared in captivity box size $(70 \mathrm{~cm} \mathrm{X70} \mathrm{cm} 70 \mathrm{~cm}$ ) and fed $10 \%$ liquid honey that was absorbed in a wad of cotton. Pesticide free cabbage leaves placed in a glass bottle filled with water and then inserted into captivity as a box laying eggs. Eggs produced were collected and placed in a petri dish with a diameter $(20 \mathrm{~cm})$ lined with blotting paper. After the eggs hatch, the larvae that there was kept in a plastic box measuring $30 \mathrm{~cm} \times 20 \mathrm{~cm} \times 5 \mathrm{~cm}$ that had previously been covered with stencil / suction paper. Each type of larvae reared in a separate box. Larvae that had entered the pre- pupae were placed in a plastic container containing soil with 5-7 cm thickness. Once formed pupae, the pupae were separated and put in a mesh cage sized $(30 \times 30 \times 60) \mathrm{cm}$. After the pupae turned into the imago, imago were transferred into plastic cages (diameter $20 \mathrm{~cm}$, height $35 \mathrm{~cm}$ ) and were fed $10 \%$ honey solution that absorbed in cotton. Eggs were laid on the leaves of broccoli used for further reproduction or allowed to hatch to get test larvae.

Feed given to the larvae of C. pavonana were broccoli leaves (Brassica oleraceae L. var. Capitata). Seeds were sown in seedling trays with 50 planting hole. The seedling trays filled with planting medium. At each planting hole was placed two cabbage seeds and basic fertilizer. Plants were watered and taken care of every day. Testing antioviposisi used about 30 day old seedlings.

\section{Making Extract}

The stem bark of Aglaia odorata plant obtained, cut into small pieces with a knife. The small pieces of stem bark were dried for 7 days. Once dried and then milled using a blender so it became fine powder. The powder was sieved with a wire mesh sieve sized $0.5 \mathrm{~mm}$, and the results of sieve extracted with methanol (ratio 1:10, W/ V) with the immersion method using a shaker and shaken with magnetic (magnetic styrrer) for 24 hours. The extract was then filtered in stages using two Buchner funnels lined with filter paper on the top funnel and the bottom funnel with Whatman filter paper no. 41 and accommodated in the Erlenmeyer flask. Dregs of the filter was rinsed repeatedly so that the filter became clear. Distillated liquid was weighed beforehand to determine the initial weight, then put into the evaporator flask and methanol was evaporated with a rotary evaporator (Buchi $\mathrm{R}-114$ ) at a temperature of $45-55^{\circ} \mathrm{C}$ with a rotation speed of $50 \mathrm{rpm}$ at -60150 to $200 \mathrm{~mm} \mathrm{Hg}$ pressure. After 
evaporation was complete, Erlenmeyer flask containing extract was weighed again. The difference between two results of weighing was the weight of the extract.

Crude extract of Methanol fraction obtained from the evaporation system was partitioned into hexane methanol $(95 \%)$ with a ratio of $1: 10(\mathrm{~W} / \mathrm{V})$ in a flask separator for \pm 8 hours. Hexane phase was washed with 95\% methanol. Hexane phase discarded while $95 \%$ methanol phase was evaporated using a rotary evaporator. Methanol fraction was partitioned again in the ethyl acetate - water system and redid the steps as above. The aqueous phase was discarded and the ethyl acetate phase obtained was stored in a refrigerator at $4{ }^{\circ} \mathrm{C}$ to be used in testing.

\section{Testing Methods}

\section{The Testing of Antioviposisi Activity}

The behavior of oviposition deterrent observed in this study was the number of eggs laid on the treatment cabbage leaf. Antioviposisi properties testing performed by the method of choice was the control and treatment of cabbage seedlings were placed in a cage (Pelealu, 2006). The concentration of the extract used was $0.25 \%$, $0: 50 \%, 0.75 \%$ and $1 \%$, and control with methanol-acetone with a ratio of $1: 1$ and Latron $77 \mathrm{~L}$ plus $0.1 \%$. Broccoli seedlings were aged 30 days (have four leaves) were sprayed with the preparation of test extract as much as $10 \mathrm{ml}$ per seedling. Control broccoli seedlings sprayed with water containing a mixture of methanol and acetone and emulsifier glisel alkyl phthalates (latron $77 \mathrm{~L}$ ). It was made plastic cage with netting roof with a size of $80 \mathrm{~cm} \times 80 \mathrm{~cm} \times 80 \mathrm{~cm}$. In the cage were put cabbage plants that have been sprayed according to the treatment so that in each cage there were 5 treatment plants, then put in 3 pairs of imago that just emerged from the pupae and fed them 10\% honey solution that absorbed in cotton. Experiments were performed five repetitions. Imago amount used in this study were 15 pairs and cabbage as many as 25 plants. Observations were made up to four days or until imago females stop laying eggs. The number of eggs laid on leaves and leaf control treatment compared with paired $t$-test. Oviposition deterrent index was calculated by the formula: Oviposition Deterrent Index $(\mathrm{IPO})=(\mathrm{KP}) /(\mathrm{K}+\mathrm{P}) . \mathrm{K}$ and $\mathrm{P}$ respectively the number of eggs laid on leaves and leaf control treatment (Renwick and Radke, 1988).

\section{RESULT AND DISCUSSION}

\section{Oviposition Deterrent Behavior Observation}

The treatment of ethyl acetate fraction of the stem bark of A. odorata had real impact against laying eggs $\mathrm{C}$. pavonana. The number of eggs laid on treatment leaves were fewer compared to the control. Extract dosage treatment of A. odorata on the concentration treated on cabbage plant seeds can significantly decrease the number of adult females laid eggs C. pavonana if it was compared with the control. Treatment extract at a concentration of 0:50\% decrease in the number of eggs laid on broccoli plant seeds treated by more than 2 times the number of eggs when compared with the control. Each treatment that was tested, the number of eggs laid by a female imago varied, with an increase in the concentration of the extract, would decrease the number of eggs laid.

Table of The Effect of A. odorata Stem Bark against oviposition C. pavonana

\begin{tabular}{|l|r|r|r|l|}
\hline $\begin{array}{c}\text { Extract / } \\
\text { Concentration }\end{array}$ & \multicolumn{1}{|c|}{ Treatment } & \multicolumn{1}{c|}{ Control } & Difference (P) & IPO \\
\hline Kontrol & $175.0 \pm 0.00$ & 0.000 & 0.000 & 0.00 \\
\hline $0.25 \%$ & $137.0 \pm 0.48$ & $62.4 \pm 13.2$ & 0.000 & 0.12 \\
\hline $0.50 \%$ & $83.0 \pm 0.94$ & $54.8 \pm 25.1$ & 0.003 & 0.35 \\
\hline $0.75 \%$ & $36.0 \pm 1.04$ & $40.12 \pm 53.5$ & 0.023 & 0.66 \\
\hline $100 \%$ & $3.8 \pm 1.12$ & $76.44 \pm 28.3$ & 0.002 & 0.95 \\
\hline
\end{tabular}


$\mathrm{P}$ values for differences between treatment and control by paired t-test. IPO = Oviposition

Deterrent Index. The complete data is on the attachment.

Extract Treatment on higher concentrations at $0.75 \%$ and $1 \%$ were able to decrease the number of eggs laid each at 4.8 and 46 times when compared with the controls.

The existence of barriers to laying eggs by female imago C. pavonana on the experimental plant might be caused by the extract that was used containing foreign compounds that are as repellent, and or can also be caused due to the closing of the towing signal contained in plants by compound signals contained in the preparation. Allyl isothiocyanate is a compound that plays a role in attracting female imago C. pavonana to lay eggs (Honda, 1995). An Oviposition Deterrent Index value (IPO) started from 0:12 to 0.95. The effect of concentration on the Oviposition Deterrent Index (IPO) showed a regular pattern. This is caused by the nature of the uniformity behavior of adult female C. pavonana and the similarity plant species that were used so that the content of stimuli on cabbage seedlings will also be the same. The existing data indicated Oviposition Deterrent Index (IPO) in the treatment of $0.25 \%, 0.50 \%, 0.75 \%$ and $1 \%$ were respectively at $0: 12,0: 35,0.66$ and 0.95 . It means that there are differences in the number of eggs laid on cabbage leaf. The higher concentration of extract the less number of eggs placed. The deterrent of laying eggs of C. pavonana might be caused by deterring components contained in the extract of A. odorata which is terpenoid class compound that can overcome the influence of stimulants found in broccoli plants. The attraction of female insects to lay eggs is a combination of responses to stimuli received by the senses of sight, mechanical, olfactory, and gustatory (Honda, 1995).

The main active compound in Meliaceae plant family that deters the development of insects is terpenoid class compound (Schmutterer, 1995). Brassicaceae plant family ,glucosinolate and the results of its hydrolysis can act as a stimulant to laying eggs (Renwick \& Chew, 1994). The presence of oviposition deterrent was caused by the active compounds contained in the extract interfere the function of ecdysteroid hormones, juvenile hormone, and some neuroendocrine hormones that play a role in controlling the process vitelogenesis. According Cusson et al, 1994, Vitelogenesis on the female imago insects is controlled by some kinds of hormone which are ecdysteroid hormone, juvenile hormone and some neuroendocrine hormones.

\section{The development of C. pavonana Insect on Larvae Control Leaf}

The progress of C. pavonana larvae on control leaf passed four instar. The body of larvae is cylinder and green. Its back is light green, and on the left and right side of the back is dark green. The larvae also has black hair. The side of the abdomen has yellow and green hair. The head fully developed but has very short antenna. The thorax has legs and grows perfectly (Fig.1).

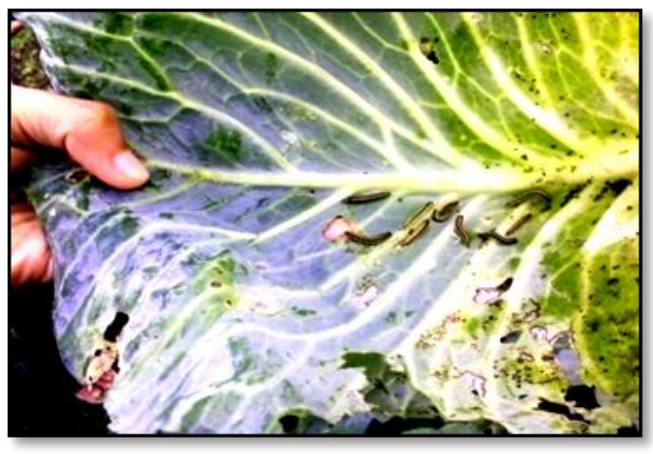

Fig. 1. Body Shape of C. pavonana Larvae

The abdomen contained a false limb (abdominal leg). Larvae has hooks or croquettes which are located at the bottom of a false leg. The size of larvae each instar varied in length (Figure 2). 


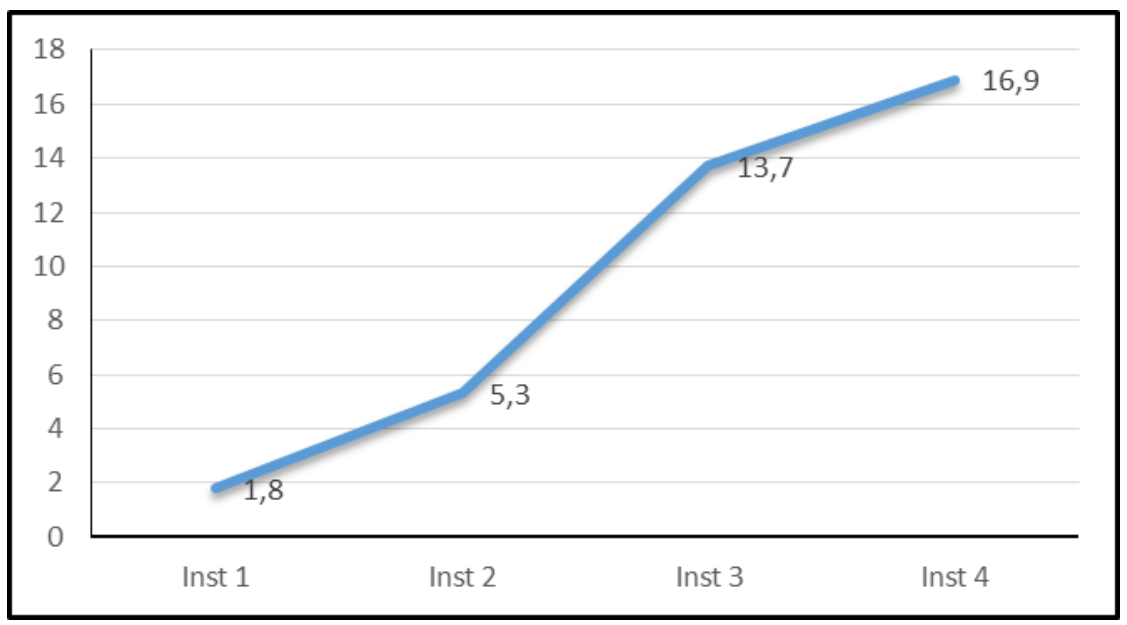

Fig. 2. Graph of The Average Length of Body at each C. pavonana Metamorphosis (mm) phase. Complete data can be found in Appendix

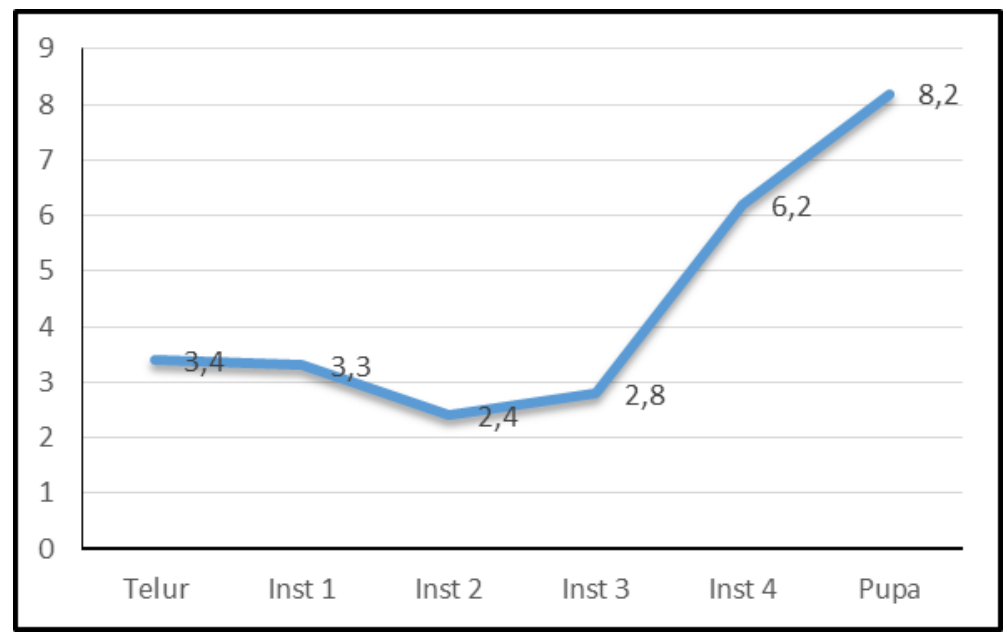

Fig.3. Graph of The Total Average Time (Days) Needed For Every C. pavonana Metamorfosis Phase. Complete data can be found in Appendix

\section{Pupae}

The results showed that the pupae are appendages that were attached to the body and protected in a cocoon. The newly formed pupae was light green and the texture was very soft Then the color changed to brown and shiny brown. The average stage of pupae was about 8.2 days and an average weight of pupae was $41.54 \mathrm{mg}$ (Fig. 13) 


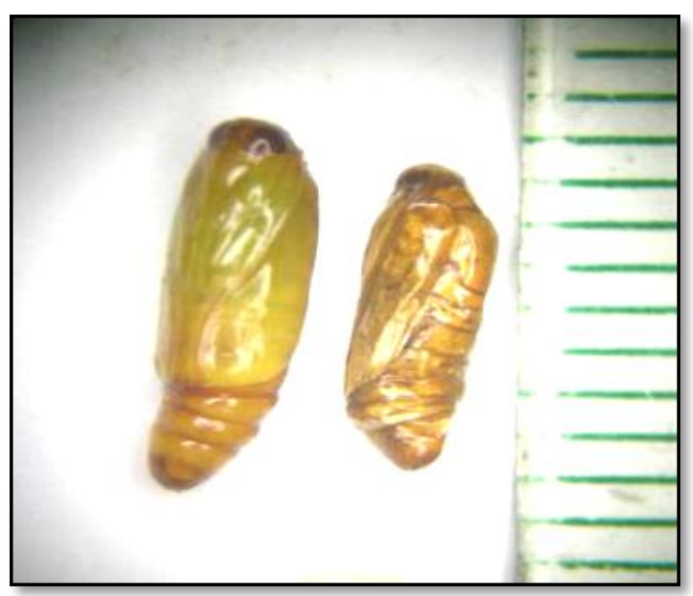

Fig. 4. The Form of C. Pavonana Pupae

\section{Imago}

After the pupae stage ends, adult insect is formed (imago). Imago has scales on its whole body. The type of its mouth is sucking. Female imago has shorter abdominal and at the top of its abdomen is oval, while male imago has longer abdomen and at the top of its abdomen is sharp.

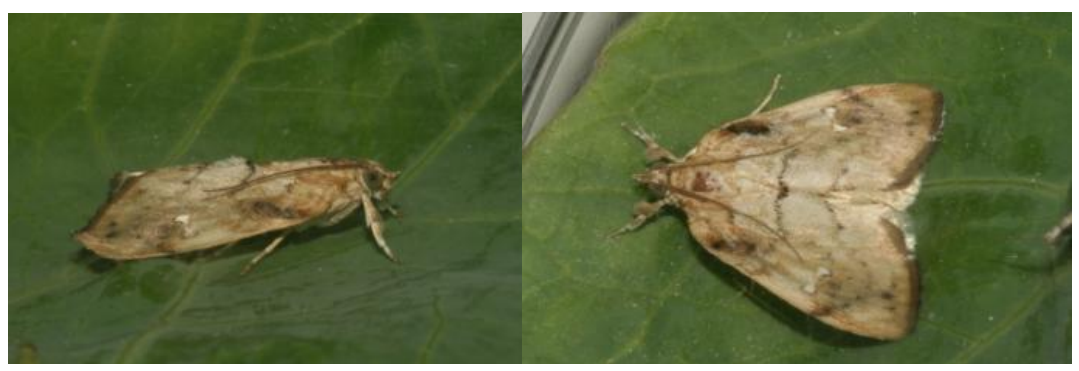

Fig. 5. Body Shape of Crocidolomia pavonana Imago

\section{Conclusion}

Bark extract of A. odorataber has real impact on the oviposition deterrent C. pavonana. Oviposition Deterrent Index (IPO) on the consentration of $0.25 \%, 0.50 \%, 0.75 \%$ and $1 \%$ are respectively at $0: 12,0: 35,0.66$ and 0.95 . It means that there are differences in the number of eggs laid on leaves cabbage. The higher concentration of the extract the less number of eggs placed. C. pavonana Fab. has a complete metamorphosis which is the development phase of eggs- larvae - pupae - imago. The average stage of C. pavonana eggs was 5.4 days. First instar larvae has an average length of $1.8 \mathrm{~mm}$ with a 3.3-day stage. Second instar larvae has average length of $5.3 \mathrm{~mm}$, with 2.4 day stage. Third instar larvae has $13.7 \mathrm{~mm}$ length, with 2.8 day stage. Fourth instar larvae has $16.9 \mathrm{~mm}$ length, and has 6.2-day stage. Pupa has a length of $7.6 \mathrm{~mm}$ and has a 8.2 -day stage. The life stage of male imago is 17 days while the female imago is 15.2 days.

\section{References}

[1] Grainge, M and S. Ahmed. 1998. Handbook Of Plants With Pest Control. Properties. New York: J. Wiley

[2] Honda, K., 1995. Chemical basis of differential oviposition by Lepidopterous insects. Arch Insect BioChem Physiol (30) : 1-23.

[3] Jacobson, M, 1997. Neem Research And Cultivation In Western Hemisphere, Pp 33-44. ProCeeding Of The Third International Neem Conference. Nairobi, Kenya, 10-15 Juli, 1986.

[4] Janpraset, J, C. Satasook, P. Sukumalanan, D.E. Champagne, and M.B. Isman, 1993. Rokaglamida, A Natural Benzoforun Insectisida From Aglaia Odorata. PhytoChemestry 32: 67-69 
[5] Pelealu, J, (2004). Ketertarikan Oviposisi Crocidolomia binotalis Zell (Lepidoptera: Pyralidae) Terhadap Berbagai Kultivar Brassica Oleraceae var. Capitata. Disertasi. Program Pascasarjana Institut Teknologi Bandung. ITB. 104 Halaman

[6] Prijono, D. 1999. Prospek Dan Strategi Pemanfaatan Insektisida Alami Dalam PHT. Badan Pelatihan Pengembangan Dan Pemanfaatan Insektisida Alami, Bogor. Pusat Kajian Pengendalian Hama Terpadu. Intitut Pertanian Bogor.

[7] Renwick, J. A. A and F. S. Chew. 1994. Oviposition behavior in Lepidoptera. Annu. Rev. Entomol. 39: $377-400$.

[8] Sastrosiswojo, S, and W.Setiawati, 1993. Hama-Hama Kubis Dan Pengendaliannya. Dalam Parmadi AH Dan Sastrosuwirjo S (Eds). Kubis. Balai Penelitian Hortikultura. Lembang. Hal 39-50.

[9] Satasook, C, M.B. Isman and P. Wiryachitra. 1992. Activity of Rokaglamide, An Insecticidal Natural Product, Against The Variegated Cutworm, Peridroma saucia (Lepidoptera : Noctuidae). Pestic Sci 36 : 53-58. 